\title{
新形势下农机技术推广的创新研究
}

\author{
崔天旭 \\ 黑龙江北大荒农业股份有限公司八五四分公司 \\ DOI:10.32629/as.v3i1.1770
}

[摘 要] 随着我国科技和经济的迅猛发展,农业与科技的联系愈发紧密,新农机技术作为提高农业生产效率的重要手段受到高度关注。基于此, 文章针对农机技术推广中存在的问题进行分析,提出加强宣传力度,完善推广体制,建设农机技术示范基地三种创新措施,希望能够推动新形势下 农机技术推广的可持续发展。

[关键词] 农机技术; 推广宣传; 农机示范基地

农机技术的推广是将科技成果向农业生产力进行转化的一种形式。新 形势下,农机技术的推广、改革以及创新成为农业发展的重要项目。扩大 农机技术的推广范围, 在新形势下做好农机技术推广研究的措施, 对我国 农业机械现代化水平的提升有着重要意义。

\section{1 农机技术推广面临的问题}

新形势下, 农民的经济需求在随着社会发展而日益加大, 只有改革陈 旧的农机技术推广体系, 才能增加农机技术的使用率。再加上农机技术的 推广是从上至下的实行, 在不断改革发展的市场经济制度中, 农机技术推 广团队的专业素质较低, 以自身经济利益为主的工作人员比较多, 不利于 农机技术推广的工作开展, 使其工作质量受到影响。而且, 在偏远的农村地 区, 交通不便, 信息闭塞, 同样使得农机技术的推广难以渗入。

\section{2 基于新形势下创新农机技术推广的对策}

2.1加强农机技术的推广宣传

要使新农机技术被广大农民群众所熟知并应用, 需要在乡镇地区进行 良好的宣传, 使农户充分认识到农业生产中农机技术发挥的重要作用。要 做好农机技术推广的任务, 需要一批高素质、能力强的推广人才队伍, 可以 快速有效的将农业技术应用到农业生产中, 通过加强农业技术人员的业务 培训提升其业务技能和实操能力, 全面的与农民进行交流沟通。在现阶段 的农机推广工作中, 想寻求更好的预期效果, 农机技术的推广方法起到了 至关重要的作用。

在新形势下, 需要不断创新农机技术的推广方法, 摒弃传统落后的推 广方式, 确保推广工作深入开展。农业生产效率和经济效益想要得到有效 的提升, 最重要的就是改变农民传统思想, 扩大新农机的使用范围。在交通 不便, 信息相对闭塞的农村地区, 为了做好农机技术推广的宣传工作, 要有 针对性的进行技术推广, 比如组织人员进行实物演示, 通过发传单来引导 农户主动了解农机技术。相关推广部门需要明确制定农机推广内容, 以互 联网为媒介, 通过信息的快速传播, 使农机技术在短时间内扩大推广范围, 从一定程度上调动农户的积极性。在农机技术推广模式上可以采取多种有 效方式, 积极开展下乡活动, 深入村镇与农民进行交流对话, 可以最直接的 了解到农民的需求和想法, 解答农户的困惑。通过与农民的互动, 来传授农 机技术知识。

\section{2 建立和完善体制}

农机技术的推广需要优秀的人才去渗透, 所以政府以及农业部门需要 采用多种途径来培养人才。推广农机技术不仅需要优秀的人才, 还需要稳 定的资金来支持,才能使推广工作良好的进行下去。传统的经济发展模式
影响着农民, 难以迅速接受全新的生产模式, 需要政府和管理部门开展农 民教学培训。为了保障农机技术的推广能够正常运转, 政府部门需要资金 的支持和投入, 同时需要提升监管力度, 让更多的部门和工作人员积极投 入到宣传工作中。农村农机技术推广工作是一个需长期贯彻的任务, 并非 一朝一夕就能看出成效的。政府应推行一些激励政策,包括给农机技术推 广人员增加补助、效益工资等, 为其创造良好的工作环境。加强队伍的专业 素质, 加大设备的投入力度。农民的文化素质需要政府以及相关部门的教育 培训, 提高其综合素质。聘请专家进行培训, 让农民能灵活的应用农机设备, 同时了解农民的诉求, 将信息上报给领导。另外, 专业人员应建立农机技术 推广网络平台, 确保农机技术推广过程中出现的问题能得到妥善的解决。

2.3 建立农机示范基地

要提升农业生产效率和经济效益, 农作物必须通过机械化的耕种, 才 能大幅度提高产量, 从而给农户带来更多的收益。在2018年2月份国家新型 工业化产业示范基地名单中, 坊子区通过坚持农机与农艺相结合的原则, 将农机示范基地的建设作为农机技术推广工作的重点, 成为我国首个以农 机命名的国家级示范基地, 其当地的农机产业已经成为农民增收致富的新 亮点。建设示范基地有利于推广和完善农机技术, 通过农机示范基地的建 设, 发挥了政府扶持农机化发展的优势, 也能有效调动农户发展农机化的 积极性, 更好的服务于现代化农业生产的各个环节。建议结合本地农业发 展实际来引进相关设备, 通过农机示范活动, 农民可以了解农机的优缺点 以及性能, 成立技能指导小组, 能够更好地将推广工作落实, 妥善处理在基 地建设过程中出现的一系列问题, 做到目标明确, 责任到人。为农户解决技 术上的疑难问题, 使农户们切实意识到使用农机机械化的优越性。

\section{3 结语}

农机技术的推广涉及多个方面, 诸多因素影响着新形势下农机技术的 推广。农机技术的推广工作需要政府及有关部门的重视, 需要长时间的改 革和创新。通过有效的应用各类农业生产设备, 使农业生产效率得到提高, 从而使农民深刻意识到农机技术的重要价值, 有助于农机技术的推广。

[参考文献]

[1]王培建.浅析新形势下农机技术的推广改革与创新[J]. 农技服 务,2016,33(02):132.

[2]金福贵,王贵秋.新形势下农机技术推广的创新研究[J].农民致富之 友,2019,(07):117.

[3]王玲.新形势下农机技术推广的创新分析[J].农机使用与维 修,2020,(02):48. 